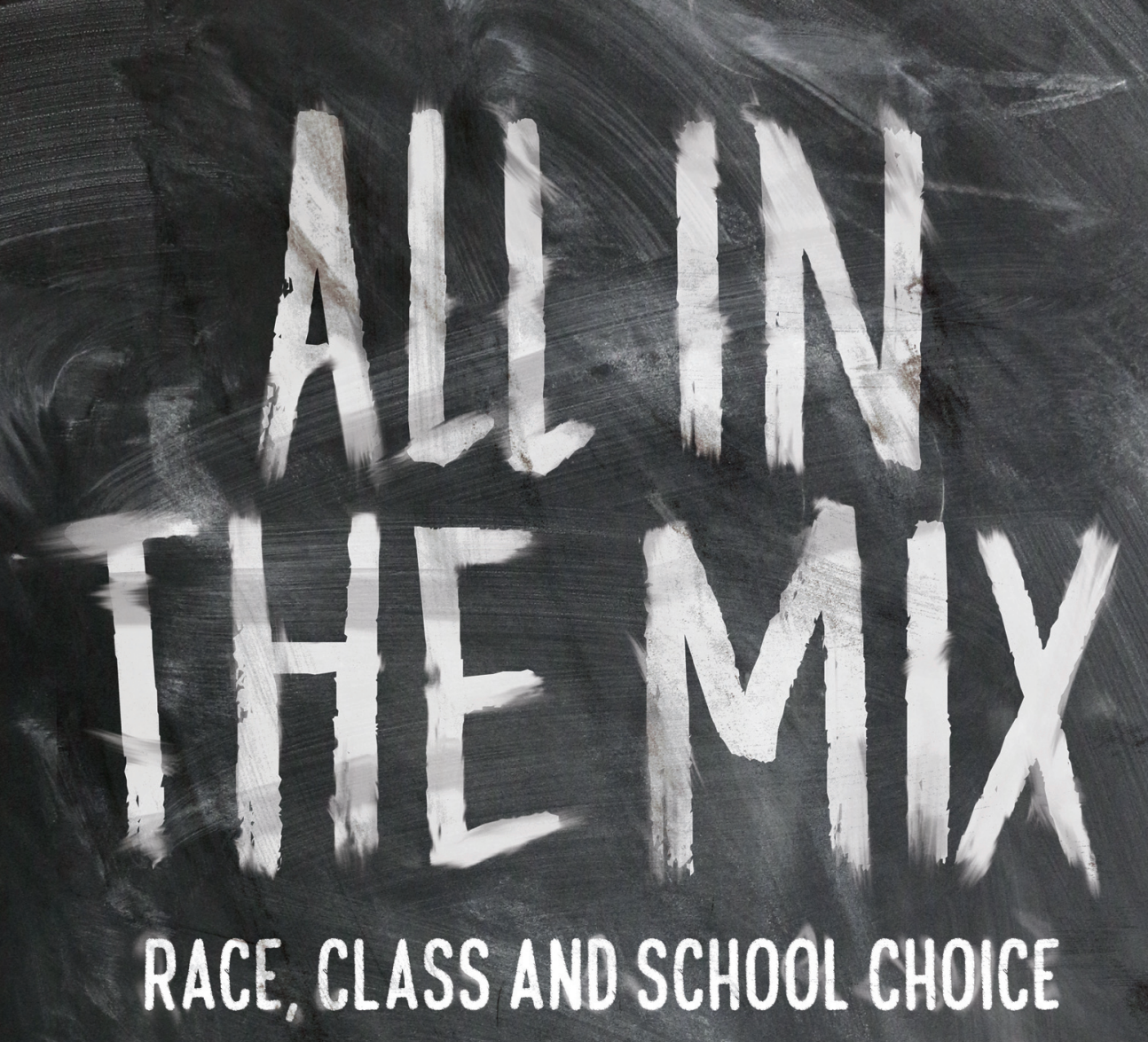

$$
\begin{gathered}
\text { BRIDGET BYRNE } \\
\text { AND CARLA DE TONA }
\end{gathered}
$$




\section{All in the mix}

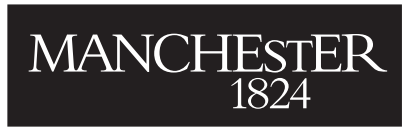

Manchester University Press 
Bridget Byrne and Carla De Tona - 9781526139306 Downloaded from manchesterhive.com at $04 / 26 / 2023$ 01:44:50PM 


\title{
All in the mix
}

\author{
Race, class and school choice
}

\author{
Bridget Byrne and Carla De Tona
}

Manchester University Press 


\section{Copyright (C) Bridget Byrne and Carla De Tona 2019}

The right of Bridget Byrne and Carla De Tona to be identified as the authors of this work has been asserted by them in accordance with the Copyright, Designs and Patents Act I988.

This electronic version of this book is also available under a Creative Commons (CC-BY-NC-ND) licence, thanks to the support of the University of Manchester, which permits non-commercial use, distribution and reproduction provided the author(s) and Manchester University Press are fully cited and no modifications or adaptations are made. Details of the licence can be viewed at https://creativecommons.org/ licenses/by-nc-nd/3.0/.

Published by Manchester University Press

Altrincham Street, Manchester Mi 7JA

www.manchesteruniversitypress.co.uk

British Library Cataloguing-in-Publication Data

A catalogue record for this book is available from the British Library

ISBN 978 o 7I90 9II5 5 hardback

ISBN 978 I 526I 39306 open access

First published 2019

The publisher has no responsibility for the persistence or accuracy of URLs for any external or third-party internet websites referred to in this book, and does not guarantee that any content on such websites is, or will remain, accurate or appropriate.

Typeset by Servis Filmsetting Ltd, Stockport, Cheshire 